\title{
An Analysis of Several Risk Factors of Central Obesity in Older Adult Mothers
}

\author{
Mariah Ulfah \\ Harapan Bangsa University \\ Purwokerto \\ mariahulfah@uhb.ac.id
}

\author{
Linda Yanti \\ Harapan Bangsa University \\ Purwokerto \\ lindayanti@uhb.ac.id
}

\author{
Maya Safitri \\ Harapan Bangsa University \\ Purwokerto \\ mayasafitri@uhb.ac.id
}

\begin{abstract}
Introduction. Central obesity influences maternal mortality, especially on the incidence of non-communicable diseases such as cardiovascular disease, diabetes mellitus, osteoarthritis, chronic renal failure and several cancers. The objective of the study: to investigate the risk factors for central obesity. Method: This research employed PLS (Partial Least Square) path analysis method. The samples were 117 older adult mothers taken with random sampling techniques. Results. The results revealed that the effect on peripheral and central obesity was food with a statistical T-value of 29.285 meaning $t>$ 1.96 with a coefficient of $(2.7 \%)$, as well as education having an effect on central obesity was food with a statistical T-value of 8.810 meaning $t>$ 1.96 with a coefficient of $(63.3 \%)$, then path analysis showed that these factors influenced central obesity by $\mathbf{4 7 . 6 \%}$ Conclusion: Factors that influence central obesity are food and education.
\end{abstract}

Keywords: hip circumference, abdominal girth, obesity

\section{INTRODUCTION}

According to the World Health Organization (WHO), overweight and obesity are increasing in prevalence and ranks fifth as a cause of death worldwide among risk factors, after high blood pressure, tobacco use, high blood glucose, and lack of physical activity [1]. In the United States, $69 \%$ of adults are overweight and $35 \%$ are obese. The increase in obesity continues to escalate into a global crisis because many cause serious chronic health conditions, including various forms of breast cancer which also show worse outcomes with obesity. These combined factors drive the 2013 American Medical Association's decision to recognize obesity as a disease[2]

One of the causes of obesity is lifestyle and environmental factors, as well as genetic factors. Lifestyle-related changes in body mass index (BMI), a measure of adiposity, are associated with an increased risk of cancer. One recent study estimated that $3.6 \%$ of all new cancer cases worldwide were caused by excess adiposity and uterine cancer, postmenopausal breast cancer, and colon cancer accounted for $63.6 \%$ of cancers caused by high BMI. Being overweight is also associated with an increase in cancer mortality and can cause $14 \%$ and $20 \%$ of cancer deaths in men and women who are overweight $\geq 50$ years old, respectively, and also $52 \%$ and $62 \%$ of the determinants of death rates in moderate number (BMI > $40 \mathrm{~kg} / \mathrm{m} 2$ ) male and female, respectively. Based on this data, it appears that an increase in BMI is associated with a high risk of cancer[3]

Obesity has great side effects on health. Obesity is associated with increased mortality, BMI over 30 has a risk of death caused mainly by cardiovascular causes[4]. In addition, other risks are insulin resistance and type 2 diabetes mellitus, metabolic syndrome, disorders of the reproductive 
system, cardiovascular disease, pulmonary disease, gallstones, bone, joint and skin diseases[5]. According to[6], obesity is at risk of dyslipidemia, hyperinsulinemia, coronary artery disease, cardiovascular disease, osteoarthritis, chronic kidney failure and some cancers (for example, endometrial, esophageal, kidney cells, pancreatic, ovarian, breast, colon and rectal disease, thyroid and melanoma), can also cause cognitive decline.

In Indonesia, based on Basic Health Research [7] data by the Ministry of Health of the Republic of Indonesia in 2013, the prevalence of overweight and obesity in children aged 5-12 years old reached $18.8 \%$. One province that has a prevalence above the national average is Central Java .Obesity in children can be a comorbid disease such as asthma, diabetes, and cardiovascular disease. Although the mechanism of its occurrence is not yet fully understood, it has been confirmed that obesity occurs because energy intake exceeds energy expenditure. The cause of obesity is influenced by genetics and the environment. Fast food or ready-to-eat-food is the primary choice for busy or consumptive parents when spending time with family in modern society. This is because the processing tends to be fast because it uses engine power, looks clean because the handlers are machines, restaurants are easy to find and because the service is always available at any time, and regardless the ordering method is (Jassen, 2004).

Physical activity is defined as body movements, especially muscles that require energy and exercise is a form of physical activity. Recommendations from Physical Activity and Health state that 'moderate physical activity' should be done for about 30 minutes or more a week. Moderate physical activity includes walking, jogging, swimming and cycling. Physical activity carried out every day is beneficial not only to get a healthy body condition but also beneficial for mental health, entertainment in preventing stress. $50-70 \%$ of a person's Body Mass Index and excess body weight are related to genetic influences. There is a $50-70 \%$ chance that a child will be overweight if both parents are obese and 25$50 \%$ if one parent is obese (Skelton, 2005). According to the results of Basic Health Research in 2018, the level of obesity in adults in Indonesia increased to 21.8 percent. This prevalence increased from the results of RISKESDAS 2013 which states that the obesity rate in Indonesia only reached 14.8 percent. Obesity itself refers to conditions where body mass index is above 27. Likewise, the prevalence of excess body weight with body mass index between 25 to 27, also increased from 11.5 percent in 2013 to 13.6 percent in 2018 (Aria W, 2018). The prevalence of central obesity among Indonesian people is also increasing. If in 2013 the central obesity rate only reached 26.6 percent, in 2018 the number would increase to 31 percent. Areas with the highest prevalence of protruding stomachs are in North Sulawesi and DKI Jakarta. As stated by the Head of the Health Research and Development Agency, Siswanto, the results of the 2018 RISKESDAS were taken from 300 thousand household samples or around 1.2 million people. According to him, the results of the 2018 RISKESDAS can represent the health face of Indonesia[7].

Like hypertension, obesity is also a risk factor for degenerative diseases such as heart disease, stroke and other vascular diseases. Early detection of obesity is expected for all visits to primary care facilities. The number of visitors to the health center and its network (aged > 15 years old) in 2017 was reported to be 
14,541,825 people, of which there were reported obesity checks of 2,830,756 people or 19.47 percent, consisting of $1,210,498$ men (17.98 percent) and 1,620,258 women (20.75 percent). From the measurement of obesity, it was obtained the percentage of obesity by 6.04 percent. The incidence of obesity in women is greater than in men. There are 4 regencies / cities that do not report the results of obesity measurements, i.e. Sukoharjo, Karanganyar, Pati and Jepara. Regency / City with the highest percentage of obesity is Magelang City, which is 100 percent of the obesity checks. Regency / city with the lowest percentage of obesity is Kendal (0.05 percent), and Banyumas Regency ranks 7 (13.6\%)[8]. Kembaran Community Health Center is one of the Community Health Centers in Banyumas Regency. Based on the health profile of Kembaran 2 community health center in 2017, it is stated that patients who are older than 15 years with a total of 856 measured body mass index in women and stated that $100 \%$ have central obesity, this makes researchers interested in requiring to investigate some of the risks factors of central obesity in Kembaran Community Health Center.

\section{RESEARCH METHODS}

\section{Study design}

This research employed path analysis, which is a structural equation model using structural equation program Structural Equation Modeling alternative methods with Visual Partial Least Squares (VPLS) [9] by looking at endogenous and exogenous factors.

\section{Settings and Respondents}

The study was conducted in Kembaran I Community Health Center in May-July 2019. The number of population in this study was 856 mothers whose obesity was measured in 2016[8], the sampling technique employed was random sampling and eventually 117 respondents were obtained, with inclusions criteria: 1) Age of older adult mothers, 2) having central obesity, 3) willing to be respondents.

\section{Instrument and measurement}

The instruments used in this study were interview and primary data collection by measuring hip circumference and abdominal girth, then calculating body mass index and measuring the ratio between hip and abdominal girth to find out central obesity.

Data analysis This study was analyzed using path analysis with PLS (Partial Least Square) because this analysis can be used to see the effect of exogenous to endogenous variables with categorical and numeric data types.

Ethical consideration. This study has passed the ethical test by the ethics committee of health research of Harapan Bangsa University. 


\section{RESEARCH FINDINGS}

The findings of this study are described as follows:

Table 1. Distribution of Respondents' Characteristics

\begin{tabular}{|c|c|c|c|}
\hline No & Variables & Frequency & Percentage \\
\hline \multirow{5}{*}{1} & Age & & \\
\hline & Older Adult & 71 & 67 \\
\hline & Early-Elderly & 15 & 14.2 \\
\hline & Late Elderly & 12 & 11.3 \\
\hline & Elderly & 8 & 7.5 \\
\hline \multirow{4}{*}{2} & Obesity & & \\
\hline & Central & 94 & 80.3 \\
\hline & Periphery & 23 & 19.7 \\
\hline & & 117 & 100 \\
\hline \multirow{3}{*}{3} & Physical Activity & & \\
\hline & Yes & 7 & 6 \\
\hline & No & 110 & 94 \\
\hline \multirow{3}{*}{4} & Food & & \\
\hline & Fiber & 15 & 12.82 \\
\hline & No & 102 & 87.18 \\
\hline \multirow{4}{*}{5} & Education & & \\
\hline & Lower & 60 & 51.28 \\
\hline & Intermediate & 53 & 45.29 \\
\hline & Higher & 4 & 3.42 \\
\hline
\end{tabular}

Table 1 shows the age category; seen that $67 \%$ are in older adult, for obesity $80.3 \%$ are in central obesity, 94\% of respondents do not do regular physical activity, 87.18 say that they often eat fast food, rarely eat fruit and vegetables, and $51.28 \%$ of education is categorized as low. Path Analysis of Direct Effect of Mothers' Characteristics on Central Obesity

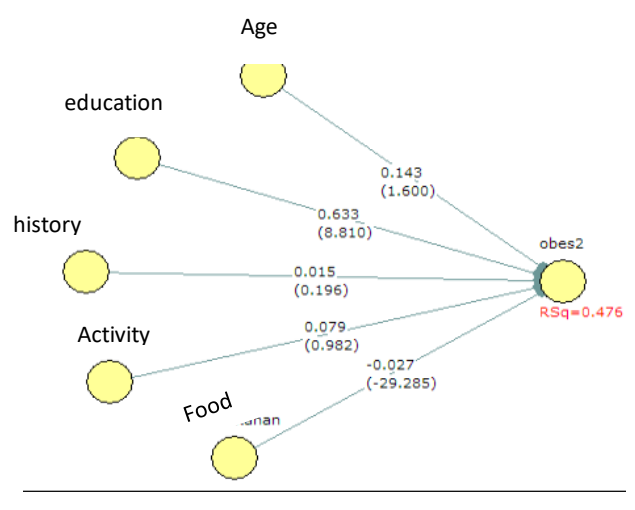

Figure 1. Path Analysis

of the Direct Effects of Maternal Characteristics on Central Obesity

Table 2 Statistical T test

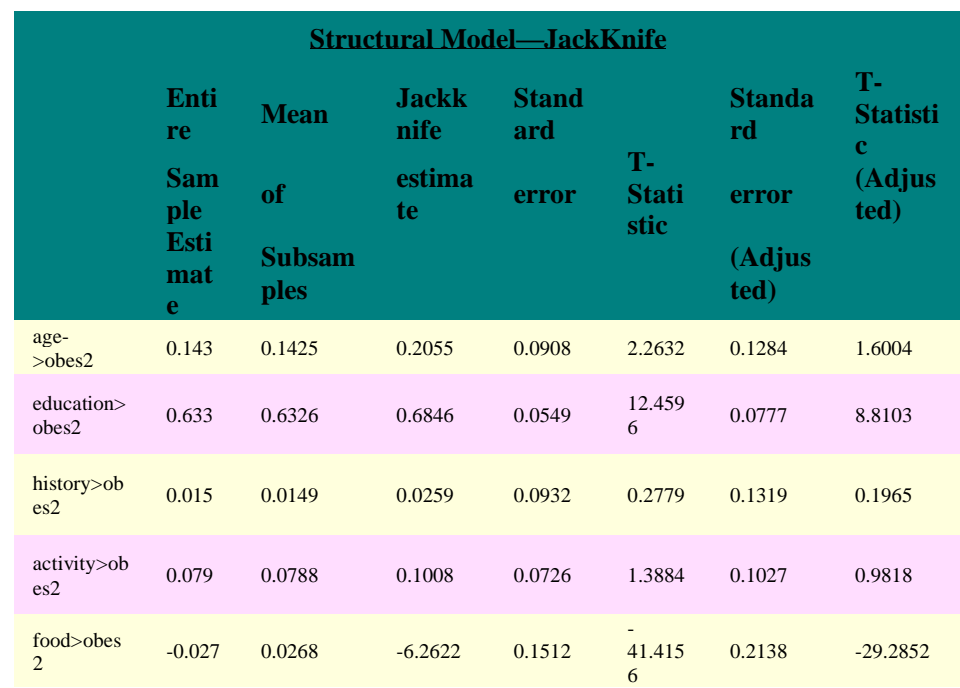

A direct correlation occurred if one exogenous variable affected another variable (endogenous). Then to find out the effect of exogenous variables to endogenous variable, the statistical $\mathrm{T}$ test was employed through the results of the VPLS output as follows with a statistical $\mathrm{T}$ value that was significant at 5 percent $(t$ count $>t$ table $=1.96)$ [9] .

\section{The Effect of Mother's Characteristics on Obesity}

\subsection{The Effect of Age on Central Obesity}

From the t test table, it can be seen that age has no effect on obesity with a 
statistical $\mathrm{T}$ value of $1.6004 \quad(<1.96)$ with a coefficient value of 0.1284 or of 12.8 percent

1.2. The Effect of Education on Central Obesity

Education has an effect on obesity with a statistical $\mathrm{T}$ test value of 8.8103 and a coefficient value of $0.0777 \quad(0.77$ percent).

1.3. The Effect of Parental Obesity History on Central Obesity

Parental history has an influence on obesity with a statistical T test of 0.196 $(\mathrm{t}<1.96)$ with a correlation coefficient of 0.0153 ( 1.53 percent).

\subsection{The Effect of Physical Activity on Central Obesity}

Physical activity affects central obesity with a statistical $\mathrm{T}$ test of $0.982(\mathrm{t}$ $<1.96)$ with a coefficient of $0.123(12.3$ percent).

\subsection{The Effect of Food on Central Obesity}

Food affects central obesity with a statistical T test of 29.285 (> 1.96) with a coefficient value of $0.0213 \quad(2.13$ percent).

\subsection{The Effect of Mothers' Characteristics on Obesity based on Hip and Stomach Circumference}

The vast effect of mothers' characteristics on obesity based on hip and stomach circumference can be seen in $\mathrm{R}$ Square which is 47.6 percent, meaning that the characteristics influence obesity by 47.6 percent, while 52.4 percent comes from other influences.

\section{DISCUSSION}

The results reveal that education and food affect the incidence of central obesity. Education has an effect on obesity with a statistical $\mathrm{T}$ test value of 8.8103 and a coefficient value of 0.633 (63.3 percent). Education is related to the socioeconomic condition of the community which is directly related to family income and it affects the prevalence of overweight [10]. The results of this study are in line with high family income, the tendency for eating patterns to change, which is an increase in intake of animal fat and protein and sugar, followed by a decrease in vegetable fat and protein and carbohydrates. Family income is also related to the frequency of eating outside the home which is usually high in fat.

Food influences obesity based on hip and abdomen circumference with a statistical $\mathrm{T}$ test of 29.285 (> 1.96) with a coefficient value of 0.027 (2.7 percent). This study is in line with research conducted by [10] which states that there is a correlation between energy intake and obesity $(\mathrm{p}=$ $0.001)$. Generally fast food is liked by adults because it tastes delicious and the price is affordable. Based on data on the frequency of fast food consumption for 1 week in Table 1.4, it is known that obese children (69.4 percent) consume the fast food with a frequency of more than 2 times a week, whereas normal children (50.0 percent) at most frequency 1 - 2 times a week. Thus, normal children consuming fast food is still within reasonable limit, while obese children consume food excessively.[10]

Other factors such as age, history of obesity in the elderly, physical activity does not affect the incidence of central obesity. Age has no effect on obesity with a statistical $\mathrm{T}$ value of $1.600(<1.96)$ with a coefficient value of 0.143 or of $14.3 \%$. This is not in line with[11] which state that obesity is very much related to age because as age increases, metabolism that occurs in the body decreases and then there will be 
biological changes. When getting older and less active in moving, body muscle mass tends to decrease which causes a slowing of the calorie burning rate, so that the body is more difficult to burn incoming calories. Increasingly, there is a buildup of energy in the body which affects obesity. Parental history did not affect obesity with a statistical $\mathrm{T}$ test of 0.196 ( $\mathrm{T}<1.96)$ with a correlation coefficient of 0.0153 (1.53\%). Obesity is influenced by genetic and environmental factors. Obesity passed down from family can be a genetic factor. But environmental factors also have a big influence, which includes lifestyle behaviors such as one's food intake and the level of physical activity undertaken. Lifestyle changes affect weight gain, which is an increase of about 50-60 calories from daily calorie intake and a decrease in physical activity can cause an increase of 2.4 kilograms of body weight at the end of the year. $95 \%$ of obese people, excess consumption can be produced by several environmental factors. Teenagers are not yet fully mature and are quickly affected by the environment. Busyness causes them to choose to eat outside or eat snacks. Furthermore, this habit is influenced by family, friends and especially television advertisements. Genetic factors are associated with weight gain, body mass index, hip circumference, and physical activity. If the father and / or mother suffers from being overweight, then the chance of the child being overweight is $40-50 \%$. If both parents suffer from obesity, the possibility of their child to become obese is $70-80 \%$. Genetic factor plays a role in weight gain. Data from various genetic studies indicate the presence of several alleles that indicate predisposition to cause obesity. In addition, there is an interaction between genetic factor and excess intake of solid food and decreased physical activity. Recent genetic studies have identified the existence of gene mutations that underlie obesity. There is a large number of genes in humans that are believed to affect body weight and adiposity. However, there is $33.3 \%$ of obese children who have nutritionally fattened and obese fathers $(22.2 \%)$, this number is higher than normal children who are only $25.0 \%$ and $15.3 \%$. Similarly, dealing with the nutritional status of mothers, the percentage of obese children having obese mothers is $27.8 \%$. This means that either both or only one of the obese parents has a tendency to give birth to an obese child. Obese mothers have a great opportunity to have obese children as well. If there is an inherited obesity factor, then there is a tendency for someone to build more fat than other people because there is a metabolic trait that is inherited, for example there is a gene inherited in the code for the enzyme Adipose Tissue Lipoprotein Lipase which is more active. Not only is the influence of genes, child obesity in this study may also be supported by environmental factors (parents' eating habits)[10]. Physical activity had no effect on obesity based on the ratio of hip and stomach circumference with the $\mathrm{t}$ test = $0.982(\mathrm{t}<1.96)$ with a coefficient of 0.079 $(7.9 \%)$. This is not in line with people who are less active in needing fewer calories than people with high activity. Someone who lives less active (sedentary life) or does not do balanced physical activity and consume foods that are high in fat, will tend to be obese. A lifestyle that lacks physical activity will affect one's body condition. Physical activity is needed to burn energy in the body. If excessive energy intake and not balanced with balanced physical activity will make it easier for someone to get fat. Based on several studies, it reveals that if physical 
activity with sufficient intensity for 60 minutes is carried out, it can reduce weight and prevent weight gain back. Children's physical activity is how children allocate their time for 24 hours in daily life to carry out certain types of activities routinely and repeatedly. In line with the the results of Bahren's research (2000) which show that activities at school are the main activity of children on school days with a total time of 300 minutes (5 hours), coupled with activities outside school such as tutoring or reciting.[12]

The vast effect of these mothers' characteristics on central obesity can be seen in $\mathrm{R}$ Square which is equal to 0.235, meaning that the effect on obesity based on body mass index is $23.5 \%$, while $76.5 \%$ comes from other influences. Obesity can be influenced by hormonal factors in the mother, also can be caused by the behavior and frequency of respondents eating.

\section{CONCLUSION AND SUGgeSTION}

Education and food factors directly influence central obesity, so it is expected that mothers can increase their knowledge related to the causes of central obesity and can pay attention to food intake that can cause central obesity. Health workers are advised to give counseling, information and education in the Integrated Guidance Post class related with central obesity and its prevention.

\section{REFERENCES}

[1] J. C. ( Krakauer, N. Y., \& Krakauer, "A new body shape index predicts mortality hazard independently of body mass index," PLoS One, vol. 7(7), 2012.

[2] S. Dua, S., Bhuker, M., Sharma, P.,
Dhall, M., \& Kapoor, "Body mass index relates to blood pressure among adults," North Am. J. Med. Sci., 2014.

[3] L. V. Campbell, "Genetics of obesity. Australian Family Physician.," 2017.

[4] C. E. Van Gaal, L. F., Mertens, I. L., \& De Block, "Mechanisms linking obesity with cardiovascular disease. Nature.," 2006.

[5] O. Roos, E. T., Lallukka, T., Lahelma, E., \& Rahkonen, "Joint associations between smoking and obesity as determinants of premature mortality among midlife employees.," Eur. J. Public Health, vol. 27(1), 135, 2017.

[6] M. Brown, C. D., Higgins, M., Donato, K. A., Rohde, F. C., Garrison, R., Obarzanek, E., ... Horan, "Body mass index and the prevalence of hypertension and dyslipidemia.," Obes. Res., 2000.

[7] Kemenkes, "Riskesdas 2018."

[8] Central Java Province Health Office, "Profil Kesehatan Provinsi Jawa Tengah 2017.," Dinkes Jateng, no. 3511351(24), 1-62, 2017.

[9] G. D. Garson, "Partial Least Squares: Regression \& Structural Equation Models.," G. David Garson Stat. Assoc. Publ.

[10] D. Rahmawati, "Faktor-Faktor yang berhubungan dengan obesitas sentral pada mahasiswa program studi kesehatan masyarakat UIN Syarif Hidayatullah Jakarta angkatan 20122014.," Gizi Indon., 2015.

[11] R. A. Wegiarti Sikalak, Laksmi Widajanti, "Faktor-Faktor Yang Berhubungan Dengan Kejadian Obesitas Pada Karyawati Perusahaan Di Bidang Telekomunikasi Jakarta Tahun 2017.," J. Kesehat. Masy., vol. 5(3), 193-, 2017. 
[12] B. J. Batara, D., Bodhi, W., \& Kepel, "Hubungan obesitas dengan tekanan darah dan aktivitas fisik pada remaja di Kota Bitung," J. E-Biomedik, 2016. 